\title{
EVALUASI PEMUNGUTAN RETRIBUSI TERHADAP PENDAPATAN ASLI DAERAH (PAD) DI KOTA PALANGKA RAYA
}

\section{Evaluation Of Retribution Leading On Regional Original Income (PAD) In Palangka Raya City}

\section{Farid Zaky Yopiannor *}

Eka Mera A

Universitas Muhammadiyah Palangkaraya, Palangka Raya, Central Kalimantan, Indonesia

email:

farid.zaky@umpalangkaraya.ac..id

\section{Kata Kunci:}

Evaluasi

Retribusi

Pasar

\section{Keywords:}

Evaluation

Retribution

Market

\section{Accepted}

Januari 2015

\section{Published}

April 2015

\begin{abstract}
Abstrak
Penelitian ini bertujuan untuk mengetahui dan mendiskripsikan serta mengevaluasi Pemungutan Restribusi Pasar Terhadap Pendapatan Asli Daerah (PAD) di Kota Palangka Raya. Penelitian ini menggunakan metode penelitian kualitatif, dimana peneliti lebih pada pengamatan, serta mendeskripsikan fenomena permasalahan yang ada melalui kata-kata, gambar. Hasil penelitian ini menunjukan perlu ada Evaluasi Pemungutan Retribusi Pasar terhadap Pendapatan Asli Daerah (PAD) Di Kota Palangka Raya. Baik itu dari input, proses, output dan outcames. Agar realisasi Retrivusi Pasar mencapai target yang diharapkan dan kontribusi pasar terhadap pendapatan asli daerah (PAD) semakin besar.
\end{abstract}

\begin{abstract}
This study aims to find out and describe and evaluate the collection of market restitution on PAD in the City of Palangka Raya. This study uses qualitative research methods, where researchers are more on observation, and describe the phenomenon of existing problems through words, images. The results of this study indicate that there needs to be an evaluation of the collection of market levies on regional original income (PAD) in the city of Palangka Raya. Either from the input, process, output, and outcomes. In order for the realization of Market Retribution to reach the expected target and the market contribution to regional original income (PAD) is greater.
\end{abstract}

\section{PENDAHULUAN}

Otonomi daerah memberikan kewenangan Daerah Otonom untuk mengatur dan mnegurus kepentingan masyarakat setempat menurut prakarsa sendiri berdasarkan aspirasi masyarakatsesuai dnegan peraturan perundang-undangan. Kebijakan otonomi daerah ini telah menetapkan kabupaten dan kota sebagai titik berat otonomi yang memberikan harapan yang baik bagi daerah untuk dapat mengembangkan diri. Salah satu untuk melihat tolak ukur kesiapan suatu daerah dalam melaksanakan otonomi daerah adalah dengan mengukur seberapa besar kemampuan keuangan suatu daerah untuk menyelenggarakan otonomi daerah atau pemerintah sendiri.
Sejalan dengan itu pemerintah daerah diharapkan mampu menggali sumber-sumber keuangan, kususnya untuk memenuhi kebutuhan pembiayaan pemerintah dan pembangunan didaerahnya melalui Pendapatan Asli Daerah (PAD) semakin besar seiring dengan semakin banyaknya kewenangan pemerintah yang dilimpahkan kepada daerah disertai pengalihan personil, peralatan, pembiyaan, dan dokumentasi kedaerah dalam jumlah besar. Dalam rangka mengoptimalisasikan pendapatan asli daerah Kota Palangka Raya juga menjadikan sektor Retribusi Daerah sebagai slaah satu sumber keuangan yang paling di andalkan. Sektor Retribusi daerah terdiri dari Retribusi Jasa Umum, Jasa Usaham dan Perizinan 
merupakan sektor yang snagat besar untuk digali untuk diperluas pengelolaannya.

Kontribusi pasar terhadap penerimaan pendapatan asli daerah diharapkan akan terus meningkat, semakin banyak lebutuhan daerah yang bisa dibiayai dengan pendapatan asli daerah menunjukan kualitas otonomo daerah tersbut semakinmeningkat. Peningkatan penerimaan rertibusi pasar harus didukung melalui upaya perbaikan struktur dan sistem yang baik guna peningkatan efektivitas pemungutan. Petugas pemungutan retribusi pasar mempunyai pengaruh terhadap efektivitas penerimaan. Semakin tinggi kemampuan pelaksanaan pungutan (SDM) maka semakin tinggi pula tingkat daerah, sehingga petugas pemungutan retribusi diduga mempunyai pengaruh yang positif terhadap efektivitas penerimaan retribusi pasar.

Dalam hal ini, Dunn (2003:608) menjelaskan bahwa istilah evaluasi mempunyai arti yang berhubungan, masing-masing menunjuk pada aplikasi beberapa skala nilai terhadap hasil kebijakan dan program. Menurut Sahya Anggara (20I4: 27I), evaluasi menilai keterkaitan antara teori (kebijakan) dan praktiknya (implementasi) dalam bentuk dampak kebijakan, yaitu dampak tersebut sesuai dengan yang diperkirakan atau tidak.

Sedangkan A.S Hornby dalam Herabudin (2016: 153) mengungkapkan bahwa evaluasi berasal dari kata evaluation yang artinya sebagai penilaian atau to find out, deside the amount of value. Selain itu, Menurut Stuffflebeam dalam Daryanto (2008:I) Evaluasi merupakan proses menggambarkan, memperoleh dan menyajikan informasi yang berguna untuk alternatif keputusan. Sementara iyu Suchman dalam Arikunto (2004:I) memandang Evaluasi sebagai sebuah proses menentukan hasil yang telah di capai beberapa kegiatan yang direncanakan untuk mendukung tercapainya tujuan. Defenisi lain dikemukakan oleh Worthen dan Sanders dalam Arikunto (2004:10) dua ahli tersebut mengatakan bahwa Evaluasiadalah kegiatan mencari sesuatu tersebut juga termasuk mencari informasi yang bermanfaat dalam menilai keberadaan suatu program, produksi, prosedur, serta alternatif strategi yang diajukan untuk mencapai tujuan yang sudah ditentukan.

Menurut Glosarium (2005:179) Otonomi daerah pungutan adalah penerimaan pemerintah sehubungan dengan jasa atau fasilitas yang diberikan atau disediakan oleh pemerintah untuk kepentingan masyarakat. Sedangkan menurut KBBI, Pemungutan adalah proses, cara, peerbuatan memungut (2007:908)

Pengertian Retribusi secara umum pembayaranpembayaran kepada negara yang dilakukan oleh mereka yang menggunakan jasa-jasa negara Sumitro dalam Kaho (2005:170). Selanjutnya,Retribusi daerah merupkan salah satubsumber pendapatan asli daerah yang penting lainnya. Retribusi daerah adalah pungutan daerah sebagai pembayaran atas jasa atau pemberian izin tertntu yang khusus disediakan atau diberikan oleh pemerintah daerah untuk epentingan orang pribadi atau badan Suparmoko (2002:85)

\section{METODOLOGI}

Penelitian ini menggunakan pendekatan kualitatif, dimana peneliti lebih pada pengamatan, serta mendeskripsikan fenomena permasalahan yang ada melalui kata-kata, gambar sehiangga dapat menggambarkan secara sistematis mengenai fakta-fakta serta hubungan antara fenomena yang diselidiki, yang berhubungan dengan masalah atau gejala yang terjadi. Dalam penelitian ini penggalian data menggunakan obsevasi langsung, wawacara mendalam dan FGD.

\section{HASIL DAN PEMBAHASAN}

Dari hasil penelitian yang telah dilakukan mengenai Retibusi Pasar di Kota Palangka Raya, maka penulis merasaada beberapa hal yang perlu di evaluasi yaitu meliputi hal-hal seperti dibawah ini : 
I. Evaluasi Input

Untuk jumlah Sumber Daya Manusia (SDM) dalam hal ini adalah petugas pemungutan retribusi pasar, perlu ada penambahan petugas pemungutan retribusi pasar dilapangan mengingat jumlah pedagang yang ada di Kota Palangka Raya begitu banyak dan luas Kota Palangka Raya yang begitu luas wilayahnya. Selain itu ada perbaikan sarana dan prasarana pasar yang ada, meskipun selama ini sarana dan prasarana pasar ada sebagian sudah memadai.

Karena sarana dan prasarana merupakan hal yang penting dalam menarik minat para pedagang untuk berjualan di pasar yang telah disediakan oleh pemerintah. Sehingga, semakin banyak pedagang yang berjualan ditempat yang di sediakan oleh pemerintah, maka semakin banyak pula jumlah retribusi pasar yang diterima oleh pemerintah, maka semakin banyak pula jumlah retribusi pasar yang diterima oleh pemerintah. Sehingga kontribusi rertribusi pasar terhadap pendapatan asli daerah semakin besar pula.

\section{Evaluasi Proses}

Berdasarkan haisl penelitian dalam melakukan pemungutan retribusi pasar masih belum tegas, baik dari segi waktu pemungutan tarif dan sakso. Hal itu bisa dilihat dari hasil penelitian dilihat dari segi waktu pemungutan retribusi tidak ada kepastian atau kesepakatan antara pedagang dan pemungut retrbusi pasar. Sedangkan jika dilihat dari segi tarif retibusi maish belum tegas. Hal itu dikarenakan retribusi pasar sifatnya tidak mengikat dan untuk besarnya tarif retribusi sedang dan pemungut yang dipungut berdasarkan kesepakatan antar pedagang dan pemungutan retribusi pasar, sehingga jika ada pedagang tidak membayar rertibusi pasar atau membayar retribusi pasar tidak sesuai dengan ketentuan aturan daerah maka pedagang tersebut tidak dikenakan sanksi seperti tertuang dalam peraturan daerah, dan selama ini belum pernah ada pedagang dikota palangka Raya di kenakan sanksi baik iru sanksi administrasi maupun sanksi pidana.

3. Evaluasi output

Ada beberapa hambatan yang ditenui dalam pemungutan Retribusi Pasar tersebut, yaitu :

a. Kesadaran pedagang masih rendah untuk membayar Retribusi

b. Retribusi daerah sifatnya tidak mengikat

c. Penarikan atau pemungutan retribusi pasar tidak tepat waktunya, misalnya pada saat pemungutan dilakukan oleh petugas Retribusi ada toko yang masih belum buka

d. Kurangnya informasi atau data tentang jumlah potensi retribusi pasar (jumlah pedagang ) yang ada.

4. Evaluasi Outcomes

Untuk dampak negatifnya karena ada beberapa masalah yang ditemui dalam pemungutan retribusi pasar, sehingga target retrbusi pasar tidak pernah tercapai dan kontribusi rertibusi pasar terhadap pendpaatan asli daerah masih kecil.

Sedangkan untuk dampakpositif dari kebijakan pemungutan retribusi pasar adalahh masyarakat khususnya ikut berpartisipasi dalam menunjang pembangunnan daerah, melalui rertibusi pasar yang mereka bayar.

\section{KESIMPULAN}

I. Dalam melaksanakan pemungutan retribusi pasar dilapangan, terdapat beberapa hambatan. Sehingga perlu adanya evaluasi baik dari input, proses, output, dan outcomes.

2. Adapun hambatan yang ditemui dilapangan pada saat pemungutan retribusi pasar dilihat dari segi inputnya adalah seperti kurangnya jumlah tenaga pemungut retribusi pasar, sarana, prasarana yang sebagian belum memadai. Sedangkan dari process pemungutan retribusi pasar adalah kebijakan 
retribusi daerah yang sifatnya tidak mengikat dan ketentuan sanksi bagi pedagang yang tidak membayar retribusi pasar masih tegas dan kurangnya kesadaran dan pengetahuan para pedagang tentang wajib membayar retribusi pasar. Sehingga bedampak pada jumlah realisasi retribusi pasar yang tidak pernah mencapai apa yang telah diharapkan atau ditargetkan.

3. Selain jumlah realisasi retribusi pasar yang tidak pernah mencapai target yang harapkan, akibat lain dari hambatan-hambatan seperti yang dikemukakan di atas adalah kontribusi retribusi pasar terhadap pendapatan asli daerah selama tiga tahun terakhir.

\section{REFERENSI}

Akdon. 2006. Strategic Management For Educational Management (Manajemen Strategik untuk manajemen pendidikan). Bandung : Alfabeta.

Anggara, Sahya. 2014. Kebijakan Publik. Bandung: CV Pustaka Setia.

Arikunto, Suharsimi dan Cepi Safrudin Abdul Japar. 2004. Evaluasi Program Pendidikan. Jakarta. Bumi Aksara

Darise, Nurlan. 2007. Pengelolaan Keuangan pada Satuan Kerja Perangkat Daerah (SKPD). PT.indeks

Daryanto. 2008. Evaluasi Pendidikan. Jakarta : Rineka Cipta.

Departemen Pendidikan Nasional. 2007. Kamus Besar Bahasa Indonesia. Jakarta : Balai Pustaka.

Dunn, William N. 2003. Pengantar Analisis Kebijakan Publik Edisi Kedua. Yogyakarta: Gadjah Mada University Press.

Herabudin. 2014. Studi Kebijakan Pemerintah dari Filosofi ke Implementasi. Bandung: Pustaka Setia.

Kaho, Josef Riwu. 2005. Prosfek Otonomi Daerah di Negara Kesatuan Republik Indonesia. Jakarta : PT.Raja Grafindo Persada

Mangkunegara, Anwar Prabu. 2006. Evaluasi Kinerja SDM. Bandung. Refika Aditama

Meleong, Lexy. 2004. Metodologi Penelitian Kualitatif. Bandung. PT Remaja Rosdakarya.

Narbuko, Cholid dan Abu Achmadi. 2003. Metodologi Penelitian. Jakarta. PT Bumi Aksara. 